\title{
Perlindungan Kawasan Hutan Dalam Rangka Pelestarian Alam Di Taman Nasional Berbak Provinsi Jambi
}

\author{
Taufik Yahya, Isran Idris \\ Fakultas Hukum Universitas Jambi \\ (taufikyahya@unja.ac.id) \\ (isranidris@unja.ac.id)
}

\section{PENDAHULUAN}

\subsection{Latar Belakang Masalah}

Hutan mempunyai kedudukan dan peranan yang sangat penting dalam pembangunan bangsa dan negara, karena hutan dapat memberikan manfaat yang sebesar-besarnya bagi kemakmuran dan kesejahteraan rakyat. Manfaat itu dapat dibedakan menjadi langsung dan tidak langsung. Di samping itu, hutan merupakan kekayaan milik bangsa dan negara yang tidak ternilai, sehingga hak-hak negara atas hutan dan hasilnua perlu dijaga dan dipertahankan, dan dilindungi agar hutan dapat berfungsi dengan baik. ${ }^{1}$ Di dalam agenda 21 Konferensi Tingkat Tinggi di Rio de Janeiro pada tahun 1992 disebutkan manfaat hutan sebagai paru-paru dunia.Indonesia memiliki hutan seluas lebih kurang 144 juta ha, hanya118 juta ha yang masih berupa hutan. Hutan seluas itu diperinci dalam hutan produksi seluas 49,3 juta ha, hutan lindung seluas 39,9 juta ha, serta hutan konservasi dan hutan lainnya seluas 29,0 juta ha. ${ }^{2}$

Di dalam Pasal 46 UU Nomor 41 Tahun 1999 ditentukan tujuan perlindungan hutan, kawasan hutan, dan lingkungannya agar fungsi lindung, fungsi konservasi, dan fungsi produksi tercapai. Ketentuan tentang perlindungan hutan semula diatur dalam Pasal 15 Undang-Undang Nomor 5 Tahun 1967, kemudian diubah dengan Pasal 46 sampai dengan Pasal 51 UU Nomor 41 Tahun 1999 ditentukan 4 (empat) macam perlindungan, yaitu perlindungan atas:

1. Hutan,

2. Kawasan hutan;

3. Hasil hutan; dan

4. Investasi. $^{3}$

Perlindungan kawasan hutan adalah suatu usaha untuk menjaga dan melindungi kawasan hutan yang telah ditentukan peruntukannya berdasarkan Surat Keputusan Menteri Kehutanan. Semua hutan yang telah ditentukan peruntukannya itu harus dipasang tapal-tapal batas yang terbuat dari beton dengan ukuran $10 \times 10 \times 10 \mathrm{~cm}$ atau kelas kayu awet I atau awet II dengan ukuran $15 \times 15 \times 130 \mathrm{~cm}^{4}$ Tujuan pemasangan tapal batas ini adalah sebagai pemberitahuan kepada masyarakat bahwa hutan itu telah ditentukan sebagai kawasan hutan. Dengan demikian, semua masyarakat dilarang untuk memotong, memindahkan, merusak, dan atau menghilangkan tapal batas tersebut. ${ }^{5}$ Di samping itu, masyarakat juga dilarang untuk

\footnotetext{
${ }^{1}$ Ahmad Redi, Hukum Sumber Daya Alam Dalam Sektor Kehutanan, Sinar Grafika, Jakarta, 2014, hal. 21.

${ }^{2}$ Hermn Haeruman, Masalah Sosial Dalam Pembangunan Kehutanan, Makalah Seminar Pascasarjana UI, Jakarta, hal. 3.

${ }^{3}$ Takdir Rahmadi, Hukum Lingkungan di Indonesia, Rajawali Pers, Jakarta, 2015, hal. 33.

${ }^{4}$ Idris Sarong Al Mar, Pengukuhan Hutan dan Aspek-Aspek Hukum (Suatu Analisis Yuridis), Makalah Bahan Penataran Tekhnis Yuridis Kawasan Hutan, Jakarta, 2003, hal. 3.

${ }^{5}$ Salim, H.S., Dasar-Dasar Hukum Kehutanan, Sinar Grafika, Jakarta, 2002, hal. 23.
} 
menduduki, dan atau mengerjakan kawasan hutan. Tetapi apabila masyarakat tetap menduduki dan atau mengerjakan hutan tersebut dengan sengaja, yang bersangkutan dapat dijatuhkan sanksi pidana sekana sepuluh tahun atau denda sebanyak-banyaknya Rp. 100.000.000,00 (Pasal 18 ayat (1) Peraturan Pemerintah Nomor 28 Tahun 1985).

Perlindungan hutan saat ini bukan hanya menjadi problem yang bersifat regional tetapi sudah merupakan problem dunia. Hal ini terkait dengan fungsi hutan dalam memelihara keseimbangan ekologis yang juga berpengaruh terhadap iklim global, seperti efek 'panas global' yang dapat mengancam keselamatan jiwa manusia. ${ }^{6}$ Pada prinsipnya yang bertanggung jawab dalam perlindungan hutan adalah Instansi Kehutanan di Daerah Tingkat I, yang meliputi: Kantor Wilayah Departemen Kehutanan, Dinas Kehutanan, Unit Perum Perhutani dan Unit Pelaksana Teknis di lingkungan Departemen Kehutanan. Namun tidak menutup kemungkinan terlibat pihak lain, seperti pemegang izin Hak Pengusahaan Hutan (HPH)/Hak Pengusahaan Hutan Tanaman Industri yang bertanggung jawab atas perlindungan hutan di areal hak pengusahaan hutannya masing-masing.

Kewenangan dan kewajiban itulah yang harus dilakukan dan dilaksanakan oleh Penyidik Pegawai Negeri Sipil dalam rangka menegakkan aturan-aturan hukum terhadap para pelaku tindak pidana di bidang kehutanan. ${ }^{7}$ Keberhasilan pembangunan dibidang kehutanan tidak saja ditentukan oleh aparatur yang cakap dan terampil, tetapi harus juga didukung dengan peran serta masyarakat.Perlunya peran serta masyarakat dalam perlindungan adalah didasari pemikiran bahwa dengan adanya peran serta tersebut dapat memberikan informasi kepada Pemerintah c.q Menteri Kehutanan dan mengingatkan kesediaan masyarakat untuk menerima keputusan. ${ }^{8}$

Taman Nasional Berbak yang luasnya 162.700 hektare merupakan kawasan pelestarian alam untuk konservasi hutan rawa terluas di Asia Tenggara yang belum terjamah oleh eksploitasi manusia. Keunikannya berupa gabungan yang menarik antara hutan rawa air tawar dan hutan rawa gambut yang terbentang luas di pesisir Timur Pulau Sumatera serta Taman Nasional Berbak adalah bagian yang Bentang Alam Hutan Gambut Berbak yang luas 238.000 hektare. Bentang alam ini juga merupakan salah satu Bentang Alam Konservasi Harimau (Tiger Conservation Landscape) di Sumatera yang direkognisi berdasarkan Peraturan Menteri Kehutanan tentang Strategi dan Aksi Konservasi Harimau Sumatera. Taman Nasional Berbak merupakan kawasan pelestarian alam untuk konservasi hutan rawa terluas di Asia Tenggara yang belum terjamah oleh eksploitasi manusia.

Taman Nasional Berbak terletak di 2 (dua) Wilayah Kabupaten yakni: Kabupaten Muaro Jambi dan Kabupaten Tanjung Jabung Timur, di pesisir timur Provinsi Jambi disekitar bagian kanan Sungai Batanghari yang dapat diakses melalui jalan darat maupun melalui Sungai Batanghari. Kawasan ini diakui sebagai kawasan hutan rawa gambut yang ekstensif dikawasan Asia Pasifik meskipun terjadi pembukaan lahan diperbatasan bagian utaranya (disepanjang Sungai Batanghari).Sebagai kawasan Pelestarian Alam, Taman Nasional Berbak kaya akan sumberdaya alam yang terdiri dari beberapa tipe ekosistem serta kaya dengan berbagai macam spesies yang merupakan sistem ekologi yang masih belum banyak diketahui. Beberapa tipe ekosistem yang ada di Taman Nasional Berbak meliputi ekosistem hutan rawa air tawar, ekosistem hutan rawa gambut dan ekosistemhutan dataran rendah denga ketinggian 0 - 20 m dpl. Kawasan Taman Nasional Berbak merupakan kawasan yang khas keadaan fisik dan ekologinya, nilai hidrologi dan biofisik, nilai sosial dan budaya, keanekargaman flora

\footnotetext{
${ }^{6}$ Siti Sundari Rangkuti, Hukum Lingkungan dan Kebijaksanaan Nasional, Airlangga University Pers, Surabaya, 1996, hal. 27.

${ }^{7}$ I.B. Ngandung, Ketenteuan Umum Pengantar ke Hutan dan Kehutanan di Indonesia, Makalah, Ujung Pandang, 2006, hal. 4.

${ }^{8}$ Yahya Hanaf, Pengukuhan Hutan dan Aspek-Aspek Hukum, Bahan Penataran Tekhnis yuridis kawasan hutan, 2003, Jakarta, hal. 7.
} 
fauna dan kekhasannya yang berpotensi untuk di kembangkan dimasa yang akan datang seperti interpretasi dan pariwisata. Berbak merupakan satu dari dua kawasan Ramsar Site di Indonesia meliputi tipe ekosistem hutan rawa gambut yang tidak terganggu seluas 110.000 ha dan hutan rawa air tawar seluas 60.000 ha. Terdapat pengurangan kawasan seluas 1500 ha yang merupakan kawasan hutan mangrove ketika berubah status dari Suaka Marga Satwa ke Taman Nasional.

Pentingnya kawasan hutan bagi kelangsungan hidup masyarakat sekitar hutan untuk memperoleh taraf hidup yang lebih baik secara ekonomi serta keinginan dari pemerintah untuk melestarikan hutan, maka dari itu perlu dilakukan penelitian tentang pengelolaan kawasan Taman Nasional Berbak yang secara jangka panjang dapat memberi manfaat bagi kedua pihak yaitu pemerintah dan masyarakat secara berkelanjutan.

Bertolak dari data luas hutan yang terdapat di Indonesia, perlu dilakukan suatu pendekatan yang bijak. Salah satu cara yang ditempuh adalah dengan pendekatan pengelolaan hutan di kawasan Taman Nasional Berbak dan hasil hutan yang dilakukan secara terencana dan bijaksana sesuai dengan peraturan perundang-undangan yang berlaku, khususnya peraturan dibidang kehutanan guna mencegah dan meminimalisir kerusakan hutan dalam mewujudkan pengelolaan hutan yang berkelanjutan.

\subsection{Perumusan Masalah}

Permasalahan dalam penelitian tentang Perlindungan Kawasan Hutan dalam rangka pelestarian alam di Taman Nasional Berbak Provinsi Jambi dirumuskan sebagai berikut:

1. Apakah upaya perlindungan yang dilakukan dalam rangka pelestarian alam di Taman Nasional Berbak Provinsi Jambi?

2. Apakah faktor-faktor yang mempengaruhi perlindungan kawasan hutan dalam rangka pelestarian alam di Taman Nasional Berbak Provinsi Jambi?

\section{TINJAUAN PUSTAKA}

\subsection{Perlindungan Kawasan Hutan}

Perlindungan hutan dan konservasi alam diatur dalam Pasal 46 sampai dengan Pasal 51 Undang-Undang Nomor 41 Tahun 1999 serta dioperasionalisasi dalam Peraturan Pemerintah Nomor 45 Tahun 2004 tentang Perlindungan Hutan sebagaimana telah diubah dengan Peraturan Pemerintah Nomor 60 Tahun 2009 tentang Perubahan Atas Peraturan Pemerintah Nomor 40 Tahun 2004 tentang Perlindungan Hutan. Agar fungsi-fungsi tersebut dapat berjalan secara optimal dan lestari, maka dilakukan usaha perlindungan terhadap hutan produksi, hutan lindung, kawasan suaka alam, kawasan pelestarian alam, taman buru, hasil hutan, tumbuhan dan satwa. Dalam Pasal 46 Undang-Undang Nomor 41 Tahun 1999 tentang Kehutanan, penyelenggaraan perlindungan hutan dan konservasi alam bertujuan menjaga hutan, kawasan hutan dan lingkungannya, agar fungsi lindung, fungsi konservasi dan fungsi produksi tercapai secara optimal dan lestari.

Perlindungan hutan merupakan bagian dari kegiatan pengelolaan hutan. Kegiatan perlindungan hutan dilaksanakan pada wilayah hutan dalam bentuk Kesatuan Pengelolaan Hutan Konservasi (KPHK), Kesatuan Pengelolaan Hutan Lindung (KPHL) dan Kesatuan Pengelolaan Hutan Produksi (KPHP). Perlindungan hutan menjadi kewenangan pemerintah dan atau pemerintah daerah. Kegiatan perlindungan hutan di wilayah dan untuk kegiatan tertentu dapat dilimpahkan oleh pemerintah kepada Badan Usaha Milik Negara (BUMN) yang bergerak di bidang kehutanan. Dalam rangka kepentingan penelitian, pengembangan, pendidikan dan pelatihan kehutanan, religi dan budaya, Menteri menetapkan perlindungan hutan dengan tujuan khusus. 


\subsection{Konservasi Sumber Daya Alam Hayati dan Ekosistemnya}

Konservasi Sumber Daya Alam Hayati dan Ekosistemnya diatur dalam UU No. 5 Tahun 1990. Pasal 1 UU No. 5 Tahun 1990 memuat pengertian-pengertian tentang konsep-konsep yang relevan dalam rangka konservasi sumber daya alam dan ekosistemnya. Beberapa di antara konsep itu perumusannya akan dikutip di sini, yakni konservasi sumber daya alam hayati, ekosistem sumber daya alam hayati, kawasan suaka alam, cagarbiosfer, kawasan pelestarian alam, taman nasional, taman hutan raya, taman wisata alam.

\section{METODE PENELITIAN}

\subsection{Jenis Penelitian}

Penelitian mengenai perlindungan kawasan hutan Taman Nasional Berbak merupaka jenis penelitian yuridis empiris.

\subsection{Pendekatan Penelitian}

Dalam penelitian mengenai perlindungan kawasan hutan Taman Nasional Berbak ini pendekatan masalah yang digunakan adalah pendekatan perundang-undangan,pendekatan konseptual serta pendekatan kasus dan pendekatan historis.

\subsection{Bahan Hukum Penelitian}

Bahan hukum dalam penelitian ini dikumpulkan melalui studi dokumen dan studi pustaka.

\subsection{Teknik Analisis bahan Hukum}

Bahan hukum primer dan sekunder yang terkumpul baik berupa konsepsi, prinsip, standar dan norma hukum nasional dianalisis secara kualitatif. Analisis kualitatif tersebut lalu diuraikan secara deskriptif dan perspektif. Analisis deskriptif perspektif ini bertitik tolak dari analisis yuridis sistematis setelah mengkaji peraturan hukum nasional yang berkaitan dengan perlindungan kawasan hutan.

\subsection{Instrumen Penelitian}

Untuk memperoleh data yang diinginkan tersebut, penelitian ini menggunakan instrumen berupa studi dokumen. Studi dokumen dilakukan terhadap peraturan perundang-undangan yang ada kaitannya dengan masalahperlindungan kawasan hutan Taman Nasional Berbak.

\section{HASIL DAN PEMBAHASAN}

\subsection{Kondisi Umum Perlindungan Kawasan Hutan Taman Nasional Berbak}

Taman Nasional Berbak merupakan kawasan pelestarian alam yang memiliki kekhasan dalam keadaan fisik dan ekologinya, nilai hidrologi dan biofisik, nilai sosial dan budaya serta keanekaragaman flora dan fauna. Berdasarkan Surat Keputusan Gubernur Hindia Belanda No. 18 Tahun 1935 ditetapkan sebagai Suaka Marga Satwa Berbak. Taman Nasional Berbak ditetapkan berdasarkan Keputusan Menteri Kehutanan Nomor: 285/Kpts;II/1992 dengan luas 162.700 Ha. Berdasarkan SK Menteri Kehutanan RI Nomor 185/Kpts-II/1992 dibentuk organisasi pengelola Taman Nasional Berbak. Meliputi 2 (dua) Wilayah Kabupaten yakni Kabupaten Muaro Jambi dan Kabupaten Tanjung Jabung Timur. Terletak dipesisir timur Provinsi Jambi disekitar bagian kanan Sungai Batanghari yang dapat diakses melalui jalan darat maupun melalui Sungai Batanghari. Batas-bastas kawasan TN Berbak yaitu Sebelah 
Utara Selat Berhala, Sebelah Selatan Taman Nasional Sembilang, Sebelah Timur Kecamatan Sadu dan Laut Cina Selatan, sebelah Barat Sunagi Berbak, Tahura dan Hutan Lindung Gambut.

Wilayah Taman Nasional Berbak dengan luas 162.700 ha membentang pada dua kabupaten, yaitu Kabupaten Tanjung Jabung Timur dan Kabupaten Muaro Jambi, Provinsi Jambi. Saat ini kawasan Taman Nasional Berbak telah dibagi menjadi tiga seksi pengelolaan antara lain:

1. Seksi Pengelolaan Taman Nasional Wilayah I yang berkedudukan di Suak Kandis

2. Seksi Pengelolaan Taman Nasional Wilayah II yang berkedudukan di Muara Sabak

3. Seksi Pengelolaan Taman Nasional Wilayah III yang berkedudukan di Air Hitam Laut.

Sejak tahun 1997Taman Nasional Berbak dikelola oleh Balai Taman Nasional Berbak sebagai Unit Pelaksana Teknis Direktorat Jenderal Perlindungan Hutan dan konservasi Alam, Departemen Kehutanan.Sebagian besar wilayah Taman Nasional Berbak berupa lahan basah, bahkan sebagai kawasan konservasi lahan basah terluas di Asia Tenggara mempunyai peranan penting bagi habitat berbagai jenis flora, fauna dan ekosistemnya, sehingga ditingkat internasional pun kawasan Taman Nasional Berbak telah ditetapkan sebagai kawasan Ramsar dan telah diperkuat oleh Pemerintah Indonesia melalui Keppres No. 48 Tahun 1991 tanggal 19 Oktober 1991. Dengan ditetapkannya kawasan Taman Nasional Berbak kedalam UndangUndang Ramsar sebagai kawasan konservasi menunjukkan nilai penting kawasan ini bagi masyarakat Indonesia maupun dunia.

Taman Nasional Berbak tidak saja dilindungi secara Nasional, tetapi juga secara Internasional yaitu dengan ditetapkan sebagai Lahan Basah. Taman nasional ini ditempuh dengan menyelusuri sungai Air Hitam Dalam. Satu dari dua Kawasan Ramsar Site di Indonesia meliputi hutan rawa gambut yang tidak terganggu seluas 100.000 ha, hutan rawa air tawar seluas 60.000 ha dan sisanya merupakan hutan dataran rendah yang umumnya berada disekitar tepi sungai, dengan kedalaman gambut mencapai 10 meter. Kawasan ini diakui sebagai kawasan hutan rawa gambut yang ekstensif dikawasan Asia Pasifik, meskipun terjadi pembukaan lahan diperbatasan bagian utaranya (disepanjang Sungai Batanghari). Kawasan Taman Nasional Berbak ditetapkan berdasarkan Surat Keputusan Menteri Kehutanan Nomor 285/Kpts-II/1992 seluas 162.700 Ha sebagai salah satu kawasan pelestarian alam yang berfungsi sebagai perlindungan sistem penyangga kehidupan.

\subsection{Upaya Perlindungan Kawasan Hutan Taman Nasional Berbak}

Kondisi fisik kawasan Taman Nasional Berbak sangat vital bagi kelangsungan aktifitas ekonomi di daerah sekitar dan di bagian hilirnya yang mata pencaharian pokoknya adalah di sektor pertanian. Di samping itu, kawasan ini juga berperan memelihara fungsi ekologis seperti menjaga stabilitas iklim, mencegah erosi, mengendalikan banjir, melestarikan biodiversity sarana penelitian dan pendidikan, wisata dan fungsi lainnya.

Taman Nasional Berbak sebagai bagian dari lingkungan yang dinilai sebagia modal pembangunan daerah maupun nasional memiliki manfaat yang nyata bagi kehidupan dan penghidupan bangsaa dan negara Indonesia, baik manfaat ekologis, sosial budaya maupun ekonomi secara seimbang dan dinamis. Untuk itu, Taman Nasional Berbak harus dikelola, dilindungi serta dimanfaatkan secara berkelanjutan bagi kesejahteraan dan kemakmuran rakyat dari generasi ke generasi. Upaya pengendalian dampak lingkungan hidup tidak dapat dilepaskan dari tindakan pengawasan agar ditaatinya ketentuan peraturan perundangundangan di bidang lingkungan hidup itu sendiri. Suatu perangkat hukum yang bersifat preventif berupa izin melakukan usaha atau kegiatan lain oleh karena itu, izin harus dicantumkan secara tegas syarat dan kewajiban yang harus ditaati dan dilaksanakan oleh penanggungjawab setiap kegiatan yang terjadi di kawasan Taman Nasional Berbak tersebut. 
Dengan demikian, adanya keikutsertaan berbagai instansi dalam pengelolaan Taman Nasional Berbak memang harus dipertegas batas wewenang tiap-tiap instansi yang ikut serta dalam pengelolaan kawasan Taman Nasional Berbak.

Keputusan Kepala Badan Pengendalian Dampak Lingkungan Nomor 08 Tahun 2002 Tentang Keterlibatan Masyarakat dan Keterbukaan Informasi dalam Proses Analisis Mengenai Dampak Lingkungan, merumuskan prinsip dasar pelaksanaannya, yaitu bahwa pengelolaan serta pemanfaatan lingkungan hidup yang berupa sumber daya alam dan ekosistemnya harus adanya kesetaraan posisi para pihak yang terlibat maupun terkait yang berhubungan dengan pengelolaan kawasan Taman Nasional Berbak transparansi dakam pengambilan keputusan, penyelesaian masalah yang bersifat adil dan bijaksana serta adanya koordinasi, komunikasi dan kerja sama di antara pihak terkait

Jadi pelestarian dan perlindungan kawasan Taman Nasional Berbak yang merupakan warisan bersama umat manusia, tidak hanya masyarakat Indonesia tetapi juga bagi masyarakat internasional. Di dalam pengelolaan Taman Nasional Berbak hendaknya mendayagunakan konsep-konsep pembangunan berkelanjutan, konsep pembangunan hak-hak masyarakat pada umumnya dan konsep pembangunan manusia seutuhnya pada khususnya untuk mendorong kemajuan di dalam pengelolaan Taman Nasional Berbak menuju lebih baik.

Pemerintah Provinsi Jambi menekankan pada upaya preventif dalam melaksanakan perlindungan hukum bagi kawasan hutan. Setiap periode tertentu, pihak Dinas Perkebunan dan Kehutanan Provinsi Jambi melaksanakan sosialisasi dan penyuluhan terkait pentingnya perlindungan fungsi hutan. Bencana tanah longsor dan banjir bandang yang pernah terjadi cukup mengingatkan masyarakat akan bahaya yang ditimbulkan oleh penebangan liar.

Berdasarkan hasil penelitian dapat diketahui bahwa alternatif pengelolaan kawasan Taman Nasional Berbak jika dilihat secara keseluruhan bahwa kriteria yang paling di prioritaskan adalah hukum. Hasil tersebut menunjukkan bahwa masih kurang tegasnya penegakan hukum dalam pengelolaan kawasan Taman Nasional Berbak. Hal ini juga terbukti dari wawancara kepada responden masyarakat diketahui bahwa masih ada sebagian anggota masyarakat yang mengambil kayu di kawasan hutan walaupun bukan menjadi mata pencaharian utama masyarakat. Setelah kriteria hukum yang perlu diprioritaskan adalah kriteria ekonomi, hal tersebut sesuai dengan hasil pengamatan di lapangan yang menunjukkan bahwa masyarakat memanfaatkan kawasan Taman Nasional Berbak sebagai lahan pertanian untuk menunjang kebutuhan ekonomi.

Selanjutnya dapat diketahui dari beberapa alternatif secara keseluruhan responden menganggap alternatif peningkatan pendapatan perlu lebih diprioritaskan karena stakeholder yang diwawancarai menganggap apabila masyarakat sudah memiliki kesejahteraan yang baik maka kecenderungan masyarakat untuk merusak hutan akan berkurang. Setelah alternatif peningkatan pendapatan alternatif berikutnya adalah sanksi Undang-Undang. Hal ini disebabkan karena pada kenyataan di lapangan masih ada oknum masyarakat yang menebang hutan baik untuk memanfaatkan kayu atau membuka lahan perkebunan, namun dapat diketahui bahwa prioritas peningkatan pendapatan masyarakat merupakan prioritas utama jika dibandingkan dengan sanksi undang-undang.

\subsection{Faktor-Faktor Yang Mempengaruhi Perlindungan Kawasan Hutan Dalam Rangka Pelestarian Alam di Taman Nasional Berbak}

Upaya perlindungan kawasan hutan sebenarnya terletak pada faktor-faktor yang mempengaruhinya. Faktor-faktor tersebut mempunyai arti yang netral, sehingga dampak positif atau negatifnya terletak pada isi faktor-faktor tersebut. Faktor-faktor tersebut adalah, Pertama, faktor hukumnya sendiri, dalam hal ini dibatasi pada undang-undang saja; Kedua, faktor penegak hukum, yakni pihak-pihak yang membentuk maupun menerapkan hukum; 
Ketiga, faktor sarana atau fasilitas yang mendukung penegakan hukum; Keempat, faktor masyarakat, yakni lingkungan dimana hukum tersebut berlaku atau diterapkan; dan Kelima, faktor kebudayaan, yakni sebagai hasil karya, cipta, dan rasa yang didasarkan pada karsa manusia di dalam pergaulan hidup.

Kelima faktor tersebut saling berkaitan dengan eratnya, oleh karena merupakan esensi dari perlindungan hukum. Dalam menjalankan funginya untuk melindungi kawasan hutan di Povinsi Jambi pihak Tenaga Pengamanan Hutan (Jagawana) mengalami kendala hal menghadapi pelaku pembalakan liar. Salah satu harapan yang dilontarkan oleh pihak Tenaga Pengamanan Hutan (Jagawana) adalah kiranya mereka dapat dibekali senjata api dengan mengikuti ketentuan peraturan yang ada tentang senjata api tersebut.

Hasil penelitian menunjukkan bahwa sebenarnya hingga saat ini sudah sangat jarang terjadi kasus-kasus tindak pidana disektor kehutanan semisal illegal loging dan pembukaan lahan di kawasan hutan Taman Nasional Berbak. Hal ini mengindikasikan bahwa sebenarnya mayoritas masyarakat sudah takut untuk melakukan perambahan hutan disekitar kawasan hutan Taman Nasional Berbak.

Namun dilain sisi, ada pula yang beralasan bahwa masyarakat melakukan perambahan hutan dan membuka lahan karena tidak mengetahui bahwa kawasan tersebut telah masuk kawasan hutan Taman Nasional Berbak hal ini dikarenakan patok dan kawasan yang dibuat oleh pihak dinas sangat jarang ditemukan, bahkan sebagian mengatakan bahwa belum ada tanda yang dipasang oleh pihak dinas yang menandakan daerah batas-batas hutan Taman Nasional Berbak.

\section{KESIMPULAN DAN SARAN}

\subsection{Kesimpulan}

a. Bahwa upaya perlindungan kawasan hutan Taman Nasional Berbak (TNB) meliputi pendekatan teknis, yuridis dan fisik baik secara preventif dan represif. Upaya tersebut dilakukan aparat kehutanan dengan tenaga pengamanan hutan (Jagawana dan PPNS) sebagai inti bersama-sama dengan masyarakat yang terpilih dan terlatih dengan bersandar pada instansi atau aparat keamanan. Upaya tersebut dengan melakukan penataan batas terhadap areal hutan yang telah ditunjuk Menteri Kehutanan sesuai dengan fungsinya untuk dikukuhkan menjadi kawasan hutan.

b. Bahwa faktor hukum, penegak hukum, fasilitas yang tersedia, masyarakat sekitar hutan, kebudayaan masyarakat merupakan faktor-faktor penting upaya perlindungan kawasan hutan dalam rangka pelestarian alam di Taman Nasional Berbak.

\subsection{Saran-Saran}

a. Disarankan membangun suatu komitmen bersama antara pemerintah dengan masyarakat dengan cara melakukan koordinasi antara departemen terkait dan pemerintah Provinsi Jambi yang mempunyai kepentingan yang besar terhadap kelestarian hutan, sehingga segala permasalahan dapat dipecahkan bersama.

b. Melaksanakan rehabilitasi hutan yang dapat dipertanggungjawabkan.

c. Melakukan audit lingkunganuntuk mengetahui besarnya kerugian yang di akibatkan oleh kegiatan manusia merusak hutan, maka audit lingkungan sudah saatnya harus dilakukan.

\section{DAFTAR PUSTAKA}

Ahmad Redi, 2014, Hukum Sumber Daya Alam Dalam Sektor Kehutanan, Sinar Grafika, Jakarta. 
Hermn Haeruman, Masalah Sosial Dalam Pembangunan Kehutanan, Makalah Seminar Pascasarjana UI, Jakarta

I.B. Ngandung, 2006,Ketenteuan Umum Pengantar ke Hutan dan Kehutanan di Indonesia, Makalah, Ujung Pandang.

Idris Sarong Al Mar, 2003,Pengukuhan Hutan dan Aspek-Aspek Hukum (Suatu Analisis Yuridis), Makalah Bahan Penataran Tekhnis Yuridis Kawasan Hutan, Jakarta.

Salim, H.S., 2002,Dasar-Dasar Hukum Kehutanan, Sinar Grafika, Jakarta.

Siti Sundari Rangkuti, 1996, Hukum Lingkungan dan Kebijaksanaan Nasional, Airlangga University Pers, Surabaya.

Takdir Rahmadi, 2015,Hukum Lingkungan di Indonesia, Rajawali Pers, Jakarta.

Yahya Hanaf, 2003, Pengukuhan Hutan dan Aspek-Aspek Hukum, Bahan Penataran Tekhnis yuridis kawasan hutan, Jakarta. 